\title{
LAO PEOPLE'S DEMOCRATIC REPUBLIC 'S DEPENDENCY ON CHINA'S INFRASTRUCTURE ASSISTANCE
}

\author{
Sigit and Jefferson Winata Bachtiar
}

\begin{abstract}
Despite an acrimonious history, being involved in the second and third Indochina War, in the past few years, Lao People's Democratic Republic (PDR) seems to have deepened its relations with China. The improvement of friendly bilateral ties between Beijing and Vientiane can be observed by the evidence of China as the largest foreign investor in the country. On one hand, Lao PDR's struggle to improve its economic its landlocked geography and the need for infrastructure assistance naturally makes the country lean more towards China. On the other hand, Beijing needs Lao PDR's geographical advantages to complete the Belt and Road Initiative (BRI) project. The objective of this paper is to analyze the evolving relationship between China and Lao PDR within the context of the BRI. This paper concludes that both parties have developed a complex interdependent relationship with China attempting to establish a solid geo-economics system while trying to assert its position in a structural power system. The act of assertion is supported by its foreign policy that is predicted to be utilized to cajole Southeast Asia countries to be part of a community of common destiny under the leadership of Beijing.
\end{abstract}

Keywords: Lao PDR, Complex Interdependence, Foreign Policy, BRI, ASEAN.

\section{INTRODUCTION}

Power shifts and the rise and fall of great powers has been at the core of the discipline of International Relations since its inception. For the last ten years, it is important to understand that there are emerging powers such as China, India, and Brazil. These occurrences affect the world order. The main focus of this article is the relationship between China's Belt and Road Initiative (BRI) and Laos/Lao People's Democratic Republic's (PDR) dependency on China's infrastructure assistance. Simultaneously, the question remains how will China affect Southeast Asia's economy and what will ASEAN response be? The subject becomes more prominent as the increasing economic success and growing influence of China offers much to the world, including Southeast Asia.

Compared to the East Asian region, in the early 2000, Southeast Asia seemed backward. East Asian countries like Japan, China, and South Korea were booming economically and impacting the rest of the region directly. Nonetheless, the environment has changed entirely as ASEAN gradually prospered. As Weatherbee observed,

The Southeast Asian subsystem is becoming an increasingly important unit of the international system. The result of three interrelated developments. It is derived in part from key regional states' increasing 
capabilities and national ambitions. It also reflects the interdependencies being established as the ASEAN region is integrated into the global economy. Finally, Southeast Asia has become a stage where great power rivalries and competition for influence are being played out. ${ }^{1}$

The objective of this article is to examine China's impact on Southeast Asian economy. The article investigates the interdependence between Lao PDR and China via the BRI as testimony to China's effect on a Southeast Asian economy. In so doing, the paper highlights the implications of China's foreign policy on Southeast Asia countries, especially Lao PDR and ASEAN's response to BRI and the South China Sea dispute.

\section{CONCEPTUAL FRAMEWORK}

'Complex interdependence' is a concept that was developed by Joseph Samuel Nye and Robert Owen Keohane in the late 1970s. The concept was developed with the understanding that the characteristics of international politics always changes and shifts as time passes by to an extent where the strength of conventional power becomes deceptive and elusive. How substantial is the change? The Modernist school believes technological advancement, such as telecommunications, jet travel and the development of social and economic interactions have resulted in 'a world without borders'. ${ }^{2}$ Conventional international patterns have disappeared with the world becoming more independent in many aspects, such as in economy and communications. In other words, interdependence affects international politics and the behaviour of states; but governmental actions also influences patterns of interdependence. Therefore, it is a reality that governments control procedures, rules, and institutions. Consequently, it can be assumed that governments indirectly regulate transnational and interstate interactions. Hence, what is interdependence? According to Keohane and Nye,

Dependence means a state of being determined or significantly affected by external forces. Interdependence, most simply defined, means mutual dependence. Interdependence in world politics refers to situations characterized by reciprocal effects among countries or among actors in different countries. ${ }^{3}$

Therefore interdependence is a situation in international politics where all actors (state and non-state actors) depend on others build upon interactions and relationship which may or may not involve cooperation and/or conflict. Interdependence then leads to growing ties between actors which results in transnational actors becoming dependent and sometimes vulnerable to each other's actions and need. There are two dimensions to this interaction. They are sensitivity and vulnerability. Sensitivity refers to the degree of responsiveness of a policy structure. Similarly, vulnerability refers to an actor's liability to suffer the values imposed by external circumstances.

\footnotetext{
${ }^{1}$ Weatherbee, Donald E, International Relations in Southeast Asia: The Struggle for Autonomy, second edition (Maryland: Rowman \& Littlefield Publishers, Inc, 2009), 4.

${ }^{2}$ Keohane O. Robert and Joseph Nye, Power and Interdependence, fourth edition. (London: Pearson.2012), 1.

${ }^{3}$ Rana, Waheeda, "Theory of Complex Interdependence: A Comparative Analysis of Realist and Neoliberal

Thoughts" International Journal of Business and Social Science 6, no. 2 (2015): 291.
} 
It is undeniable that international regimes have an effect on interdependence. The structure of a system indicates the distribution of capabilities among actors. In a traditional international political system, states are the most important units. A state is categorized along the distribution of strength in accordance to its power, importance and numbers (unipolar, bipolar, multipolar, etc.). ${ }^{4}$ Structure is therefore distinguished from the process, which refers to bargaining conduct within a power structure. The structure of a system affects the type of regime. In return, the regime influences governmental actions and the decision-making outcome within a system. The other thing worth mentioning is that Neoliberals believe that international politics can no longer be divided into 'high' (for instance, national security and military power) or 'low' politics (for instance, economic, social and environmental issues) due to the complexity of the world we live in. The most prominent aspect of 'complex interdependence' is the integration of both elements - power politics and economic liberalism. Despite growing economic interdependence and the willingness to cooperate, the possibility of conflicts cannot be easily ignored. Keohane and Nye stated that in an interdependent relationship, competition between all parties related will exists even when immense benefits can be expected from cooperation. In addition, Keohane and Nye emphasized that interdependence is not evenly balanced. Furthermore, they contend that it is asymmetries in dependence that will most likely influence for states in their dealings with one another. Less dependent states will often use the interdependent relationship as a source of power to bargain over issues and outcome. ${ }^{5}$

There are three main characteristics of complex interdependence. ${ }^{6}$ First is the existence of multiple channels of communication. The relationship between government elites with a variety of entities such as banks, multinational cooperation and transnational organization. Multinational firms and banks are important as they influence the process of policy making in various countries. Such influence does not only make countries sensitive to each other but the impact on domestic environment is also prevalent. Second is the absence of hierarchy in domestic or foreign policy issues. The line between domestic and foreign issues are obscured as they are intertwined and sensitive to each other's behaviour. High politics, such as military power remain relevant but other issues related to economy, social and environmental are equally important. Third, the role of the military force cannot be discounted. Conventional issues tend to emphasize the importance of having a powerful military force as there exists threats that may jeopardize the survival of one's states. Therefore, in certain circumstances, force is necessary to ensure the survival. While the effect of employing military force is often uncertain but its usage does prevent external threats from augmenting. Having said that, in a globalized world states are highly connected and as such the use of force may not be the best way to solve issues. States understand that modern defence technology has the capacity to maximize cost and damage done to other actors. With this realization, the decline of the use of military force on solving issues has now become a norm in the world.

As mentioned before, interdependence refers to reciprocal situation where actors depend on each other. In the case of Lao PDR and China, both have national interests which need to be fulfilled. However, in the process of attaining it, China tends to assert its position by utilizing its structural power which allows Beijing to elevate its status as an economic power and so forth. The three complex interdependence characteristics are clearly present in bilateral ties. While China employs multiple channels of communications and does not make a difference between domestic and foreign policy, the most noticeable characteristic is the

\footnotetext{
${ }^{4}$ Keohane O. Robert and Joseph Nye, Op. Cit., 18.

${ }^{5}$ Ibid.

${ }^{6}$ Keohane O. Robert and Joseph Nye, Op. Cit., 20.
} 
absence of military force in bilateral relations. Because of Lao PDR's infrastructure needs, China does not have to use military force to invest in BRI projects in the state.

\section{CHINA'S FOREIGN POLICY AND SOUTHEAST ASIAN COUNTRIES}

Before addressing the relationship between Laos and China, it is pertinent to have a broader view of China's foreign policy in Southeast Asia. In so doing, Lao PDR's connection with China as a member of ASEAN will be more easily understood. Southeast Asia has always been special in China's foreign policy. This is due to geography, historical background, and the migration of ethnic Chinese to the region. In the postwar period, China's relations with the Southeast Asia has evolved through distinct phases. First, it started when Chinese Communist Party (CCP) began supporting guerilla movements in the region after sweeping to power in 1949. These efforts influenced the formation of the short-lived Southeast Asia Treaty Organization (SEATO) in 1954 and the more enduring ASEAN in 1967 - then a bloc of five non-communist States comprising Indonesia, Malaysia, the Philippines, Singapore, and Thailand. ASEAN was created, to serve as a stronghold against outside influences, especially China's support for communist insurgencies in the region. By the 1970s after China and the Soviet Union split, Beijing established formal diplomatic relations with Malaysia, the Philippines, and Thailand. The Vietnamese invasion of Cambodia in December 1978, which overthrow the Khmer Rouge, further strengthened China's relations with noncommunist Southeast Asia. The relationship also grew significantly throughout the 1990 after the Asian financial crisis, encouraging negotiations on the ASEAN-China Free Trade Area (ACFTA), whereby an agreement was reached in 2002.

Then, during a speech to the Indonesian parliament in October 2013, President Xi Jinping referred explicitly to a shared future involving China and ASEAN, "the ChinaASEAN community of shared destiny is closely linked with the ASEAN community and the East Asia community. The two sides need to bring out their respective strengths to realize diversity, harmony, inclusiveness and common progress for the benefit of the people of the region and beyond". 7 In addition, Xi's predecessor, Hu Jintao, began using the "common destiny" terminology in 2007 to describe trans-national relationship and in discussions regarding China's neighboring diplomacy. ${ }^{8}$ China's "common destiny" concept foresees inclusiveness and win-win cooperation but in reality it was as an attempt to integrate neighboring countries into the Chinese domain of influence. Then, as China began to rise economically, its influence once again became prevalent in the neighbourhood through economic diplomacy.

It is mindful to understand that China's foreign policy cannot be described by merely observing it with one specific point of view. China utilizes a variety of diplomatic, economic, and military instruments to promote its strategic interests in Southeast Asia. These instruments have evolved and changed as China's growth progresses. The manner in which China is involved in Southeast Asia is crucially important as background information to understand the Laos-China relations. In terms of China's investments in Southeast Asia, most of the projects are related to infrastructure which are at various stages including but not limited to the planning stage, feasibility study, or currently under construction. Indonesia currently leads the investment list at $\$ 93$ billion, followed by Vietnam and Malaysia at $\$ 70$

\footnotetext{
${ }^{7}$ Stromseth Jonathan, "the Testing Ground: China's Rising Influence in Southeast Asia and Regional Responses,” The Brooking Institutions (November 2019): 2.

${ }^{8}$ Kai Jin, "Can China Build a Community of Common Destiny?," The Diplomat, November 28, 2013 , https://thediplomat.com/2013/11/can-china-build-a-community-of-common-destiny/
} 
billion and $\$ 34$ billion respectively. ${ }^{9}$ China is now Cambodia's largest funder, investing roughly $\$ 12.6$ billion in 2017 alone. Beijing is also behind the funding of $\$ 7$ billion ChinaLaos railway project.

Simultaneously, Beijing expects to advance its economic and political ambitions in mainland Southeast Asia. China is developing new sub-regional initiatives, such as the Lancang-Mekong Cooperation (LMC) mechanism. Initially, LMC was established to promote economic and social development of the Mekong region. By investing in the region, it can be assumed that China considers this as a vehicle to ensure the BRI project progresses at a steady pace. The LMC was established in 2015 and it involves six countries in the Greater Mekong sub-region. They are Cambodia, China, Laos, Myanmar, Thailand, and Vietnam. Beijing has sponsored over \$22 billion under the LMC in order to support projects focusing on technological connectivity and industrial development.

And lastly, China's foreign policy is closely related to its BRI projects. In order to support and complement the BRI, China's investments in Southeast Asia is coupled with working closely with ASEAN states to maximize the benefits of BRI. In some instances, Belt and Road related corridor economies involve developing domestic actions in ASEAN member states to support much needed infrastructure development. Therefore China encourages Southeast Asian states through appropriate planning and management that fully highlights the costs and benefits of BRI projects, directly and indirectly in the neglected areas where development is slow or absent.

On one hand, it is expected that BRI will promote China- Southeast Asia relations in terms of integration of Chinese influence in the region. On the other hand, policies to promote trade facilitation in the Belt and Road corridor economies does boost exports of local economies in Southeast Asia. Of course, for China, its influence complements the promotion and success of infrastructure projects under BRI. However, Beijing's attempts to connect the region and enhance connectivity should be viewed cautiously. China's investments and assistance in infrastructure projects in Southeast Asia are tied closely to achieving a "community of common destiny". At the same time, the interdependency bears the characteristics of multiple channels of communications, the non-presence of any hierarchy as well as the absence of any form of military force in launching or initiating Chinese investments under the context of BRI in Southeast Asia. The following part will discuss the close interdependent relationship between China and Laos which is a case study of the extent to which China's influence in the region is steadily growing.

\section{LAO PDR'S SOCIO-ECONOMIC CIRCUMSTANCES}

Laos is a land-locked and mountainous state. It has a total area of 236,800 square kilometres and borders with the Kingdom of Cambodia, the People's Republic of China, the Republic of the Union of Myanmar, the Kingdom of Thailand and the Socialist Republic of Vietnam. ${ }^{10}$ Vientiane is its capital city as well as political, economic and cultural centre of the state. Strong economic growth has enabled Lao PDR to move from a low-income economy to a lower middle-income country. The economy grew at a rate of 7.5 percent in 2014 compared to an average of 8 percent over 2011 to 2013. ${ }^{11}$ The country's economic growth depends greatly on natural resources. From 2005 to 2013, the hydropower and mining sectors combined generated about one third of the country's economic growth. The natural resources

\footnotetext{
9 Jamrisko Michelle, “China No Match for Japan in Southeast Asia Infrastructure Race,” Bloomberg, June 22 , 2019, https://www.bloombergquint.com/china/china-no-match-for-japan-in-southeast-asia-infrastructure-race.

${ }^{10}$ United Nations, Country Analysis Report: Lao PDR (Vientiane: United Nation, 2015), 2.

${ }^{11}$ Ibid.
} 
sector has a high ratio of capital to labour, which produced approximately 18 percent of Lao PDR's gross domestic product (GDP) in 2013 for only 22,000 people. Hence, the economic growth was therefore, not able to generate a significant rise in shared growth and employment.

Lao PDR is an ethnically diverse country. The country has 49 officially recognised groups and up to hundreds of sub-groupings. There are four main ethno-linguistic groups (Lao-Tai, Mon-Khmer, Hmong-Lu Mien and Chine-Tibetan). Lao-Tai is the official language; however many ethnic groups do not speak it. Different socio-cultural traditions and low levels of literacy characterizes these groups living in remote mountainous areas. Lao PDR is also a country where both matrilineal and patrilineal social organization can be found. It has the distinction of being one of the few countries left in the world where matrilocal residence, matrilineal inheritance, and bi-lineal descent and kinship still exist for a large group of women, notably women of the Lao Lum tradition.

The population is estimated to be at 6.8 million. ${ }^{\mathbf{1 2}}$ The lack of vital registration and statistics on international migration makes such estimates imprecise. The population is relatively young, with 58 percent under the age of 25 and an estimated median age of 22 years in 2015. Life expectancy at birth is estimated at 65.8 years for both sexes. With current trends in infant and under five mortality rates, life expectancy in Lao PDR is not expected to reach 70 years until 2036.

\section{LAO PDR AND CHINA RELATIONS}

The bilateral relations between Lao PDR-China mostly involves trade and assistance on a variety of areas. China and Laos were allies during the Vietnam War in the 1970s known as the second Indochina War. Then, the relationship continued to deteriorate due to the SinoVietnamese war known as the third Indochina War in 1979. At that time, Laos was caught in the conflict between China and Vietnam. Laos was troubled as it did not want to upset China but eventually it sided with Vietnam. Tensions gradually abated and the relationship between Laos and China led to the visit of a delegation to China by Prime Minister Kaysone Phomvihane in 1989 where agreements on consulate, cultural cooperation, temporary agreement on border issues, and visa exemption were signed. ${ }^{13}$ Then in December 1990, Chinese Premier Li Peng went to Vientiane marking a turning point in bilateral interactions. The following years were filled with visits by leaders of China and Laos to each other's countries. Next, Laotian leaders, Phoune Sipraseuth, the then Vice President of the Council of Ministers and Minister of Foreign Affairs alongside Prime Minister Khamtay Siphandone paid a visit to China in 1993. Furthermore, Bounnhang Vorachith, the then Vice President of Lao PDR, as a guest of China, attended the G20 Hangzhou Summit in September 2016. ${ }^{14}$ During the conference, President Xi Jinping stated that he hoped that the new leadership of Lao PDR will continue friendly ties with the Chinese Communist Party (CCP). From then on, bilateral interactions gradually became important to both sides and Laos-China relations progressed to benefitting both parties. Interestingly enough, the development of their friendly bilateral relations took the form of China becoming a major investor, an important aid provider, and a valuable source of development experience. ${ }^{15}$ In return, Laos became a strategic goldmine due to its geographical importance in China's BRI project.

\footnotetext{
12 Ibid, 3

${ }^{13}$ Shanghai Institutes for International Studies, Assessment and Prospect of China Laos Development Cooperation (Shanghai: Shanghai Institute, 2016), 13.

${ }^{14}$ Ibid, 14

15 Ibid, 17.
} 
It is worth mentioning that Laos' economic development started in 1986 which led to the establishment of rational distribution and redistribution of all incomes, prices set by market and so forth. The Lao PDR leadership realised that a rising China would benefit its own development and decided to take the opportunity to grow closer to Beijing. Vientiane was impressed with China's rapid economic development and steady growth. But the growth of Laos' economy depended greatly on infrastructure development. Therefore, Laos realized that by working with China, it could overcome its geographical disadvantages through the infrastructure connectivity projects like that of the BRI in order to transform the state from 'a landlocked country' to a land-linked country'. Coincidentally, the BRI project launched by China has a higher degree of similarity with Laos' development strategy. Not to mention, the improvement and development in spaces like agriculture, electricity, and industry are fundamental for Laos socio-economic development. ${ }^{16}$ China's assistance to Laos in these areas are crucial and currently continues to grow steadily. In agriculture cooperation, Beijing has introduced a higher level of technology and production alongside pest control technology and so forth which has brought considerable profit for Laos. Then, in the realm of technical cooperation, apart from the cooperation in hydropower which takes place in the form of Lancang-Mekong Cooperation, China has also allocated funding for Laos in broadcast television and satellite communication's sectors.

\section{LAO PDR'S DEPENDENCE ON CHINESE INFRASTRUCTURE ASSISTANCE}

Most BRI projects includes hydropower dams, extensive railway, and oil and gas pipelines that have been planned to connect the Southwestern City of Kunming to Singapore through Malaysia. Due to its geographical location, Laos is part of this rail initiative. In other words it indicates that landlocked Laos plays an important role in achieving China's far reaching strategic objective in Southeast Asia. Thus, it is natural that China takes the efforts to deepen its relations with Laos. Not surprisingly, China utilizes its financial diplomatic instrument to achieve its strategic interest in Laos by being the largest foreign investor and aid provider. ${ }^{17}$

In 2019, China-Laos relations were marked by the $10^{\text {th }}$ anniversary and it was celebrated by the upgrading of bilateral relations to a comprehensive strategic cooperative partnership. As part of the celebrations, the "Visit China-Laos 2019" initiative was launched to augment tourism between both countries. Bilateral relations became further enhanced when China actively invested in transportation infrastructure, building of hydropower dams, China-Laos friendship school development, assistance to construct a military hospital. Lao PDR offered more than that to the Chinese. Not only is Laos one of the members of LMC making hydropower a potentially lucrative industry, the country is also rich in natural resources, such as minerals and rubber that have not seen their fullest extraction commercial yet. From a more strategic standpoint, boosting the connectivity between two countries equals to a more efficient and affordable distribution of Chinese goods to Lao markets. Similarly, Chinese investments can be used to harness Laos' resources, tourism and realestate sectors.

Although, Lao PDR's geographic location and mountainous topography play an important role for the connectivity of BRI projects, the same topography accords some challenges to Chinese investors. The China-Laos railway that runs from the northern border to the central capital of Vientiane crosses more than 150 bridges and passes through almost

\footnotetext{
${ }^{16}$ Ibid, 18.

${ }^{17}$ Eleanor Albert, "China Digs Deep in Landlocked Laos," The Diplomat, April 24, 2019, https://thediplomat.com/2019/04/china-digs-deep-in-landlocked-laos/
} 
half as many tunnels, which is expected to be completed by December $2021 .^{18}$ Like what China did for Bolivia, Nigeria, Pakistan, and Venezuela, Beijing also has sponsored, built, and launched a telecommunication satellite for Laos. ${ }^{19}$

Allowing China to be the largest foreign investor and aid provider comes at a price. China's preferred financing for projects is dominated by extending long-term lines of credit. But in Laos, public debt has grown to more than 65 percent of GDP. ${ }^{20}$ With the rising debt, this naturally makes Laos more reliant on China. Not surprisingly, Rajiv Biswas stated in VOA News that "Laos has accumulated significant external debt over the past decade in relation to major new hydroelectric projects, as well as Belt and Road infrastructure projects." Furthermore, Germany's Kiel Institute examined certain data last year and concluded that Beijing has become the world's biggest lender, overtaking groups like the International Monetary Fund and the World Bank. Between 2000 and 2017, many countries became debt bound to China, from less than $\$ 500$ billion to more than $\$ 5$ trillion, a tenfold increase. $^{21}$

Laos as one of the countries in the indebted list, has shown that its relations with Beijing has certain repercussions. For example, Laos resisted joining ASEAN in blaming China for its aggressive actions in the South China Sea. This is because Laos is in desperate need to make sure the pending rail line project linking China and Laos with its neighbours progresses to the fruition stage. Moreover, Jonathan Stromseth of VOA News also indicated that Lao PDR was also one of the first countries, along with Cambodia urged to sign on to the promotion of China's vision of a community with common destiny. ${ }^{22}$ Evidence of China's growing involvement indicate Lao PDR and Cambodia relations come with expectation attached.

Clearly, the relationship between Lao PDR and China falls in the category of interdependent ties. Lao PDR's economy is heavily reliant on natural resources. The country was not able to generate enough employment but with the help of China in sectors like hydropower, mining, forestry and services, this has significantly helped Lao PDR move from a low-income economy to a lower middle-income country. ${ }^{23}$ Between 2005 and 2013, hydropower and mining sectors combined generated about one third of the country's economic growth. It is heavily evident that China with its hydropower and infrastructure assistance has indeed helped Lao improve its economic performance. With BRI being a massive project involving construction of railways, oil and natural gas pipelines, ports and airports, communication system and other infrastructures, it is expected that Laos will assist China create a new form of connectivity from Asia to Europe. Simultaneously, this will benefit counties like Laos which are desperate to market their products easily to an expanded growth area. More importantly, the success of BRI in places like Laos is likely to enhance the stature of the Chinese economic model which then adds to Beijing's influence expansion on a global scale.

It is useful to understand that BRI reflects and operates within a liberal world order despite China's socialist economic orientation. The interdependence system is composed of cumulative and mutually reinforcing forms of interactions and norm-based relationships,

\footnotetext{
${ }^{18}$ Xinhua, "2 tunnels Dug through in China-Laos Railway Construction,” Xinhua, April 15, 2019. http://www.xinhuanet.com/english/2019-04/15/c_137979085.htm

19 Ibid.

${ }^{20}$ Ibid

${ }^{21}$ VOA, “Analysts: Rising Debt Burden Could Make Laos More Reliant on China,” VOA News, June 8, 2020, https://www.voanews.com/east-asia-pacific/analysts-rising-debt-burden-could-make-laos-more-reliant-china ${ }^{22}$ Ibid.

${ }^{23}$ United Nation, Loc. Cit.
} 
distinctive from those existing before $1950 .{ }^{24}$ The production of economic value and trade has expanded from a traditional exchange of physical goods across borders to a complex system of transactions. Among other, this involves global knowledge and capital flows, assistance from private and public entities for infrastructure development, educational system, bargaining between firms, nations, and banks. Contemporary trade involves continuous multidirectional and networked flows of things, people, training, investment, which now takes place in a world order without borders. ${ }^{25}$

Furthermore, such an environment of deep interdependence has the capacity to do away with the use of military force and be substituted with the "creation and manipulation of structural power" instead. ${ }^{26}$ In other words, with structural power, a state has the ability to shape environments as well as has the capacity and power to hurt another. But states with structural power usually will choose to be more positive in order to achieve profits which are much more valuable, less costly then waging war to gain power or influence.

The strategic environment of complex interdependence has created incentives for China in its foreign policy goals. Beijing frames strategic policies through its structural influence by enhancing economic growth of other states. In Lao PDR's case, China harnesses the interdependence it has with Lao PDR in multiple ways. China is in need of Laos' geographic circumstances in order to proceed with its colossal project but at the same time Laos is in need of assistance from China. Complex interdependence between these two countries forces them to adjust their behaviour according to the needs of each other. Of course China uses and manipulates its structural power to create a favourable environment in cooperating with Laos to achieve greater gains and avoid losses. However, as Hutt observed, despite its economic improvements, Lao PDR is vulnerable as it does not have a lot of options since it is struggling to pay its debts to China ${ }^{27}$. Thus, it is not surprising when Lao PDR seems to be closer and for this reason, it can be assumed that ties with China are gradually strengthening. In other words, Vientiane regards China as the only way out from poverty and stagnant economic performance.

In China's perspective, Lao PDR is a state that helps to fulfil its worldly ambitions through BRI projects. As BRI is progressing, China will be able to develop a large-scale geoeconomics system by employing the concept of community of common destiny will aim to deliver mutual gains for all participants. In reality BRI helps China domestically, to reignite Chinese economic growth, especially in construction-related heavy industries with considerable overcapacity. ${ }^{28}$

\section{CHINA'S BELT ROAD AND INITIATIVE AND ITS IMPLICATIONS TO SOUTHEAST ASIAN COUNTRIES}

As Lao PDR has proven, working with China has its benefits, more so when a state is in need of foreign assistance. Most countries in Southeast Asia are concerned with sustaining a stable and promising economic performance over the long term. As an economic organization, ASEAN represents a region that has both developing as well as low to middle-income countries in need of trade, infrastructure investments and development assistance. Most countries in Southeast Asia are not bothered about international order per say as it is not an

\footnotetext{
${ }^{24}$ Palgrave Studies of Internationalization in Emerging Markets, China's Belt and Road Initiative. Edited by Zhang, Wenxian, ed (Germany: Springer International Publishing, 2018), 37

${ }^{25}$ Ibid.

${ }^{26}$ Ibid., 39

${ }^{27}$ Hutt David, "How Worried Should Laos Be About Its Debt Problems?," The Diplomat, July 13, 2018, https://thediplomat.com/2018/07/how-worried-should-laos-be-about-its-debt-problems/

${ }^{28}$ Palgrave Studies, Op. Cit., 41
} 
issue which needs immediate resolution as it does not bring much benefits to their national goals or survival. This drives most Southeast Asian countries to the conclusion that the Chinese approach is a profitable option. At the same time, its constructive diplomacy in the region, as well as the economic advantages it brings, has helped China weather clashes of interest with individual ASEAN members. Most prominently, these involve the South China Sea dispute and Beijing's dominance over the headwaters of the Mekong River.

The Belt and Road Initiative has become the most visible platform for advancing China's diplomacy and achieving a community of common destiny in Southeast Asia. Launched in 2013, BRI has become a tool to connect with Southeast Asia infrastructure, through trade, and investment links for China. Prominent projects in Southeast Asia have includes investments in hydropower dams, oil and gas pipelines, and extensive railway plans to connect the Southwestern City of Kunming not just to Laos and Thailand, but eventually to Singapore through Malaysia. Therefore, in the long run, BRI will have a major effect on Southeast Asia countries especially Laos, Vietnam, Thailand, and Malaysia. In short, Beijing hopes BRI will allow it to exert enough influence on these countries in order to reduce dependence on the West in terms of exports.

Frankly, Southeast Asian countries have recognized the opportunities that come with engaging with Xi's signature initiative as part of their broader approach towards China. However, challenges do exists when Southeast Asia's prominent role within the BRI has certain repercussions which has forced Beijing to recalibrate how it is approaches projects in the said countries. Continued regional anxiety about the U.S.-China trade war and political realignments in a number of Southeast Asian States following elections or ahead of key have had an impact on the BRI. Yet, Southeast Asian countries like Lao PDR continue to collaborate with China because it gives enormous benefits in the long run.

\section{ASEAN AND ITS RESPONSES TO CHINA'S BEHAVIOUR}

Despite the BRI projects initiated by Beijing, the South China Sea dispute has had an impact on China's standing in Southeast Asia. Not surprisingly China's stand and claims regarding the South China's Sea dispute have built up tensions with Southeast Asian claimant countries. As a result, the dispute has hindered the expected achievement of China's vision of one community one destiny. But the fact that there is no unified position among ASEAN members regarding the South China Sea's dispute due to the differences of ASEAN countries' alignment to major powers has assisted China tremendously. What has happened, repeatedly is that Beijing has leaned on individual ASEAN members primarily Cambodia and Laos and preempted ASEAN from issuing strong or meaningful statements on the South China Sea at ASEAN annual summits. Although this is the case, in terms of BRI, China's rising economic influence has generated unease and pushback across the region, and ASEAN countries appear to be skilful in the way they negotiate with China over infrastructure projects in the region. Within this context, China is also showing a capacity to learn from its mistakes and has made huge adjustments to placate ASEAN member countries. To repair damaged relations, China strongly courted Southeast Asian participation in its Second Belt and Road Forum in Beijing in April 2019. Nine of the ten ASEAN countries' representative attended the forum with the exception of Indonesia. It can be assumed that it was likely due to the fact that President Joko Widodo was occupied by his re-election bid rather than a deliberate act to antagonize China. ${ }^{29}$

\footnotetext{
${ }^{29}$ Tiezzi Shannon, "Who Is (and Who Isn't) Attending China"s 2nd Belt and Road Forum?," The Diplomat, April 27, 2019, https://thediplomat.com/2019/04/who-is-and-who-isnt-attending-chinas-2nd-belt-and-roadforum/
} 
It should be noted that at the state level, there is a diversity of responses among ASEAN countries both to China's rise and to the intensification of great power rivalry between China and the US. Former Singaporean diplomat Bilahari Kausikan observed that Southeast Asian countries concurrently "balance, hedge and band-wagon" as the situation warrants - an intuitive response that has been "honed by centuries of hard experience" and is now "embedded in our foreign policy DNA". 30

\section{CONCLUSION}

China is expanding its influence and interests in Southeast presents both geopolitical challenges and potential economic benefits to Southeast Asian countries. ASEAN countries' individual responses to China's rise depends on geography, economic opportunities, threat perceptions, historical experience, and other factors. China has skillfully utilized a variety of diplomatic and economic to advance its strategic interests and foreign policy priorities in the region. In terms of BRI, China seems to want to reconnect with Southeast Asia through the concept of community of common destiny. Within this context, Lao PDR's relations with China provides us with an insight to the extent to which China is important in offering infrastructure assistance. China and Lao PDR have built an interdependence relationship via BRI. Both parties have attempted to create an environment where cooperation is highly emphasized in order to gain greater mutual profits and avoid disadvantages.

On one hand, while China is trying to develop structural power and assert its position in the region, Lao PDR has no choice but to depend more on China since it has to take care of its basic domestic needs. On the other hand, as the BRI progresses, changes in relations are inevitable and the question remains how China will react or realign as time goes. Yet, China will continue to collaborate with Lao PDR in BRI projects with the hope of exerting enough influence to capture a large share resources and advantages which would help reduce its dependence on Western countries for trade and investments. Against this background, while many claimants of the South China Sea respond to China according to one's geopolitical and economic needs, Lao PDR has no such considerations to make as it is a landlocked country. Its main concerns lie within the realm of how to pay back Chinese debts. ASEAN responds to the South China Sea dispute by hedging and balancing China though economic interactions. Nonetheless, how will low income countries like Lao PDR react once their economies improve and their standing in ASEAN improves. Will Lao PDR then stand together with ASEAN in matters concerning the security of the South China Sea? It remains to be seen as for the moment, Lao PDR has no option but to remain neutral due to its domestic needs.

\section{REFERENCES}

Albert, Eleanor, "China Digs Deep in Landlocked Laos," The Diplomat, 24 April, 2019. https://thediplomat.com/2019/04/china-digs-deep-in-landlocked-laos/, accessed on December 2019.

"Analysts: Rising Debt Burden Could Make Laos More Reliant on China," VOA News, 8 June 2020. https://www.voanews.com/east-asia-pacific/analysts-rising-debt-burden-couldmake-laos-more-reliant-china, accessed on December 2019.

\footnotetext{
${ }^{30}$ Stromseth, Op. Cit., 6.
} 
Balaam, N. David and Bradford Dillman, Introduction to International Political Economy, London: Pearson, 2014.

Chaisse, Julien and Mitsuo Matshushita. "China's 'Belt And Road' Initiative: Mapping the World Trade Normative and Strategic Implications," Journal of World Trade. Vol. 52, No.1 2018, pp.163-186.

Global Security, "Laos-China Relations," Globalsecurity.org, https://www.globalsecurity.org/military/world/laos/forrel-china.htm, accessed on December 2019.

Hutt, David, "How Worried Should Laos Be About Its Debt Problems?," The Diplomat,13 July , 2018. https://thediplomat.com/2018/07/how-worried-should-laos-be-about-its-debtproblems/, accessed on December 2019.

Jamrisko, Michelle, "China No Match for Japan in Southeast Asia Infrastructure Race," Bloomberg, 22 June, 2019, https://www.bloomberg.com/news/ articles/2019-06-23/china-nomatch-for-japan-in-southeast-asia-infrastructure-race, accessed on December 2019.

Kai, Jin, "Can China Build a Community of Common Destiny?," The Diplomat, 28 November, 2013. $\quad$ https://thediplomat.com/2013/11/can-china-build-a-community-ofcommon-destiny/, accessed on December 2019.

Kazianis, Harry, "Established Power" vs. "Rising Power," The Diplomat, 5 September, 2012. https://thediplomat.com/2012/09/established-power-vs-rising-power/, accessed on December 2019.

Keohane, O. Robert and Joseph Nye, Power and Interdependence, fourth edition. London: Pearson, 2012.

Lee, En Xin, "ASEAN: What You Need to Know About The Globally Important Group," CNBC, 26 April, 2018, https://www.cnbc.com/2018/04/26/asean-what-you-need-to-knowabout-the-globally-important-group.html, accessed on December 2019.

Liu Zhen, "What's China's 'Nine-Dash Line' and Why Has It Created So Much Tension in the South China Sea," South China Morning Post, 12July, 2016, https://www.scmp.com/news/china/diplomacy-defence/ article/1988596/whats-chinas-ninedash-line-and-why-has-it-created-so, accessed on December 2019.

Lohman, Walter, "China's influence in Southeast Asia flows through the Mekong," Geopolitical Intelligent Services, 2016.

Lohman, Walter, "Southeast Asia's Future Tied to Great Power Competition," Geopolitical Intelligent Services, 2020.

Mardell, Jacob, “The 'Community of Common Destiny' in Xi Jinping's New Era," The Diplomat, 25 October, 2017. https://thediplomat.com/2017/10/the-community-of-commondestiny-in-xi-jinpings-new-era/, accessed on December 2019. 
Obe, Mitsuru and Marimi Kishimoto, "Why China is Determined to Connect Southeast Asia by Rail," Nikkei Asian Review, 9 January 2019. https://asia.nikkei.com/Spotlight/CoverStory/Why-China-is-determined-toconnect-Southeast-Asia-by-rail, accessed on December 2019.

Parasmeswaran, Prashanth, "Southeast Asia and China's Belt and Road Initiative," The Diplomat, 15May, 2019, https://thediplomat.com/2019/05/southeast-asia-and-chinas-beltand-road-initiative/, accessed on December 2019.

Rana, Waheeda. "Theory of Complex Interdependence: A Comparative Analysis of Realist and Neoliberal Thoughts," International Journal of Business and Social Science, Vol. 6, No. 2. 2015, pp. 290-297.

Shanghai Institutes for International Studies, "Assessment and Prospect of China-Laos Development Cooperation," 2016.

Stromseth, Jonathan, "The Testing Ground: China's Rising Influence in Southeast Asia and Regional Responses,” The Brooking Institutions, 2019.

The World Bank, "The World Bank In Lao PDR. Where We Work,"18 April, 2020. https://www.worldbank.org/en/country/lao/overview, accessed on December 2019.

Tiezi, Shannon, "Who Is (and Who Isn't) Attending China's 2nd Belt and Road Forum?," The Diplomat, 27 April 2019. https://thediplomat.com/2019/04/who-is-and-who-isntattending-chinas-2nd-belt-and-road-forum/. accessed on December 2019.

United Nations, “Country Analysis Report: Lao PDR,” 2015.

Weatherbee, Donald E., International Relations in Southeast Asia: The Struggle for Autonomy, second edition, Maryland: Rowman \& Littlefield Publishers, Inc. 2009.

Wenxian, Z., (ed). China's Belt and Road Initiative, Palgrave Studies of Internationalization in Emerging Markets, Germany: Springer International Publishing, 2018.

World Bank, Belt and Road Economics: Opportunities and Risks of Transport Corridors, Advance Edition. Washington, DC: World Bank Publications, 2019.

Xinhua, "2 tunnels Dug through in China-Laos Railway Construction," Xinhua, 15 April, 2019. http://www.xinhuanet.com/english/2019-04/15/c 137979085.htm, accessed on December 2019.

Zhou, Laura, "Five Things to Know about the Lancang-Mekong Cooperation Summit," South China Morning Post,9 January 2018. https://www.scmp.com/news/china/diplomacydefence/article/2127387/five-things-know-about-lancang-mekong-cooperation, accessed on December 2019. 